\author{
Ondrej Štefaňak \\ Uniwersytet Konstantyna Filozofa w Nitrze \\ (D) https://orcid.org/0000-0001-9362-993X
}

\title{
Wpływ polskiej szkoły socjologicznej na badania religijności na Słowacji ${ }^{1}$
}

\begin{abstract}
Although after the political change in 1989 it is possible to scientifically study the phenomenon of religiosity also in post-communist countries, it should be humbly recognized that the authentic sociology of religion in Slovakia is still in statu nascendi. This is evidenced, for example, by the fact that in the most famous Slovak sociological journal called "Sociology" only one issue has been devoted to the topic of religiosity during last 30 years ("Sociology", 2001). We can claim, that researching of religiosity in Slovakia is almost like discovering a "virgin land". At the same time it should be acknowledged that the development of research of religiosity in the Slovak reality was most positively influenced by the Polish school of sociology. The purpose of this study is to describe the outlined impact and emphasize its importance for researching of Slovakian religiosity.
\end{abstract}

Key words: Poland, religiosity, Slovakia, sociology of religion

\section{Wstęp}

W ramach opisywania wpływu polskich naukowców na rozwój nauki w innych krajach Europy i świata warto zwrócić uwagę na wpływ wybitnych polskich socjologów religii na rozwój badań nad religijnością na Słowacji. Ten wpływ był i jest znaczący - częściowo ze względu na bliskość językową oraz częściowo ze względu na podobne realia socjoreligijne narodów z północnej i południowej strony Tatr. Chociaż po zmianie ustrojowej w 1989 roku również w krajach post-

${ }^{1}$ Praca była wspierana przez Słowacką Agencję ds. Badań i Rozwoju w ramach umowy Nr APVV-17-0158. 
komunistycznych można badać zjawisko religijności, należy z pokorą uznać, że autentyczna socjologia religii na Słowacji jeszcze ciągle znajduje się in statu nascendi. Świadczy o tym np. fakt, iż w najbardziej znanym słowackim czasopiśmie socjologicznym pod nazwą „Sociológia” przez ostatnich 30 lat tematowi religijności poświęcono tylko jeden numer (,Sociológia”, 2001). Można więc stwierdzić, jak to kiedyś napisał jeden z polskich socjologów, że badania nad religijnością na Słowacji przypominają odkrywanie „dziewiczej krainy” (Zemło, 2009).

W świetle zarysowanego kontekstu należy uznać, że na rozwój badań nad religijnością w realiach słowackich największy wpływ wywarła polska szkoła socjologiczna (lubelska, katowicka, warszawska, krakowska, poznańska i inne), która wiąże się przede wszystkim z takimi nazwiskami jak: Władysław Piwowarski, Janusz Mariański, Wojciech Świątkiewicz, Edward Ciupak, Witold Zdaniewicz, Sławomir Zaręba, Maria Libiszowska-Żółtkowska, Irena Borowik, Józef Baniak i inni. Oprócz pośredniego wpływu polskich socjologów religii na rozwój badań nad religijnością na Słowacji (wyrażającego się poprzez bogatą literaturę przedmiotu lub współpracę w ramach projektów badawczych) ów wpływ był i jest również bardziej bezpośredni (wykształcenie kilku socjologów religii, kilkunastu teologów pastoralnych oraz religioznawców). Celem niniejszego opracowania jest opisanie owego bardziej bezpośredniego wpływu oraz podkreślenie jego znaczenia dla badań nad religijnością na Słowacji. Artykuł składa się z trzech części: Władysław Piwowarski oraz badania nad religijnością Kamila Kardisa; Janusz Mariański oraz badania nad religijnością młodzieży Ondreja Štefaňaka; Wojciech Świątkiewicz oraz badania nad religijnością L’ubora Gála.

\section{Władysław Piwowarski oraz badania nad religijnością Kamila Kardisa}

Jednym z nestorów polskiej socjologii religii jest prof. Władysław Piwowarski, autor ponad 500 prac naukowych. Urodził się 1 stycznia 1929 roku w Mokrzyskach koło Brzeska (zmarł 4 sierpnia $2001 \mathrm{w}$ Lublinie). W 1961 roku obronił na Katolickim Uniwersytecie Lubelskim doktorat z filozofii chrześcijańskiej w zakresie filozofii praktycznej i został zatrudniony na KUL w Sekcji Teologii Pastoralnej. Habilitował się w 1967 roku, sześć lat później (1973) uzyskał tytuł profesora nadzwyczajnego, a w 1982 roku został profesorem zwyczajnym. Był wybitnym i zasłużonym socjologiem religii, autorem kilku podręczników, wieloletnim kierownikiem Katedry Socjologii Religii na Wydziale Nauk Społecznych KUL. Jego zainteresowania naukowe skupiały się wokół socjologii religii i katolickiej nauki społecznej. Wśród jego publikacji znajdują się dzieła o charakterze monograficznym, encyklopedycznym i podręcznikowym, między innymi: Religijność wiejska w warunkach urbanizacji, 1971; Religijność miejska $w$ rejonie uprzemystowionym, 
1977; Religijność ludowa - ciagłość i zmiana, 1983; ABC katolickiej nauki społecznej, 1993; Socjologia religii, 2000. (Mariański, 2004a, s. 291-292).

Piwowarski z pasją starał się poznać i opisać prawdę o religijności Polaków. Jego diagnozy nieraz prowadziły do kontrowersji. Pisał odważnie i kontrowersyjnie o stanie świadomości religijnej polskich katolików. Należał do wielu towarzystw naukowych w kraju i za granicą (np. do Towarzystwa Naukowego KUL, Polskiego Towarzystwa Socjologicznego czy Görres-Geselschaft). Pod jego kierownictwem stopień naukowy doktora uzyskało kilkanaście osób, m.in. Mirosław Kalinowski (1993), Kazimierz Święs (1994) i Wiesław Łużyński (1999) (Święs, 2018, s. 187-188). Wśród jego doktorantów znalazł się również Kamil Kardis z Litwy, który później zamieszkał na Słowacji, gdzie pracuje naukowo (Uniwersytet Preszowski w Preszowie, Katedra Filozofii i Religioznawstwa). Chociaż formalnie obronił pracę doktorską pod kierunkiem Kazimierza Ryczana, uważa się za ucznia Piwowarskiego.

Kardis urodził się 23 września 1976 roku w Wilnie na Litwie. W 1994 roku uzyskał maturę. W latach 1994-1995 studiował na Akademii Teologii Katolickiej w Warszawie, a w latach 1995-1999 na Wydziale Teologii KUL. W okresie 1999-2003 odbył studia doktoranckie na Wydziale Nauk Społecznych KUL, najpierw pod kierunkiem Piwowarskiego a następnie pod kierunkiem Ryczana. W 2004 roku otrzymał stopień doktora socjologii na podstawie rozprawy pt. Wartości podstawowe społeczeństwa polskiego w świetle listów pasterskich Prymasa Kardynała Stefana Wyszyńskiego i Episkopatu Polski 1946-1981 (Skrzyniarz, 2018a, s. 461).

W 2011 roku Kardis uzyskał habilitację w zakresie religioznawstwa na Preszowskim Uniwersytecie w Preszowie, a w 2018 roku na tejże uczelni otrzymał tytuł profesora religioznawstwa. Jego zainteresowania naukowe skupiają się przede wszystkim wokół socjologii religii, socjologii rodziny oraz socjologii kultury i grup etniczych. Słowacki uczony litewskiego pochodzenia należy do różnych towarzystw naukowych na Słowacji i w Polsce (jest m.in. ekspertem Polskiej Komisji Akredytacyjnej, członkiem Słowackiego Towarzystwa Socjologicznego oraz Rady Naukowej Wydziału Teologii Greckokatolickiej na Preszowskim Uniwersytecie w Preszowie) (https://www.unipo.sk/greckokatolicka-teologicka-fakulta/katedry/ kfr/7/kkardis/op/ [dostęp: 28.01.2021]).

Wśród badań empirycznych oraz bazujących na nich publikacji Kardisa znajdują się dzieła o charakterze podręcznikowym i monograficznym, m.in.: Základy sociológie [Podstawy socjologii], 2009; Náboženstvo v kontexte paradigmy sociálnej zmeny [Religia w kontekście paradygmatu zmiany społecznej], 2013; Vybrané kapitoly zo sociológie náboženstva I [Wybrane rozdziały z socjologii religii I], 2013; Sociológia náboženstva II [Socjologia religii II], 2016; Kapitat społeczny a religia w perspektywie społeczeństwa ryzyka, 2017; Úvod do kultúrnej a sociálnej antropológie [Wstęp do antropologii kulturowej i społecznej], 2019 (http://www.pulib. sk/web/kniznica/epc/autor/Kardis+Kamil+\%281976\%29 [dostęp: 28.01.2021]). Dla rozwoju badań nad religijnością na Słowacji ważne jest również to, że od 2004 roku pod kierownictwem Kardisa różne stopnie naukowe uzyskało wielu 
studentów - m.in. Anna Krehlíková (2014), Jana Štefančíková (2015) i Lubomír Jankura (2020) - których prace dyplomowe (doktorskie, magisterskie lub licencjatskie) niejednokrotnie bazowały na badaniach socjoreligijnych (https://kzp.pulib. sk/\#/library/kzp?supervisor=Kardis\%20Kamil [dostęp: 28.01.2021]).

\section{Janusz Mariański oraz badania nad religijnością młodzieży Ondreja Štefaňaka}

Wśród najwybitniejszych polskich socjologów religii znajduje się również doktor honoris causa prof. Janusz Mariański. Lista jego prac naukowych obejmuje ponad 1500 tytułów oraz ciągle się poszerza. Urodził się 6 września 1940 roku w Borowie koło Sierpca na Mazowszu. W 1972 roku obronił na Katolickim Uniwersytecie Lubelskim doktorat z filozofii chrześcijańskiej w zakresie socjologii. Habilitował się w 1979 roku, dziesięć lat później (1989) uzyskał tytuł profesora nadzwyczajnego, a w 1992 roku został profesorem zwyczajnym. Jest wybitnym i zasłużonym socjologiem religii, autorem kilku podręczników i mnóstwa publikacji książkowych, wieloletnim kierownikiem Katedry Socjologii Moralności (1984 - 2012) oraz Katedry Socjologii Religii (2001 - 2012) w Instytucie Socjologii KUL (Smyczek, 2015a, s. 385-386).

Zainteresowania naukowe Mariańskiego skupiają się wokół socjologii religii, socjologii moralności i katolickiej nauki społecznej. Wśród jego licznych publikacji znajdują się dzieła o charakterze monograficznym, encyklopedycznym i podręcznikowym, m.in.: Kryzys moralny czy transformacja wartości? Studium socjologiczne, 2001; Leksykon socjologii religii, 2004; Religijność społeczeństwa polskiego w perspektywie europejskiej, 2004; Sekularyzacja i desekularyzacja w nowoczesnym świecie, 2006; Socjologia moralności, 2006; Emigracja z Kościoła. Religijność młodzieży polskiej w warunkach zmian społecznych, 2008; Religia w społeczeństwie ponowoczesnym, 2010; Przemiany moralności polskich maturzystów w latach 1994-2009. Studium socjologiczne, 2011; Kontrowersje wokót relacji religii i moralności. Tożsamość czy rozbieżność? Studium socjologiczne, 2014; Leksykon socjologii moralności. Podstawy, teorie, badania, perspektywy, 2015; Godność ludzka w kontekście społecznym. Szkice ze społecznego nauczania Kościoła katolickiego, 2017; Kondycja religijna i moralna młodzieży szkót średnich w latach 1988-1998-2005-2017, 2018. (Fel, Zemło, 2020, s. 489-588).

Lubelski uczony jest socjologiem o niekwestionowanym autorytecie w dziedzinie socjologii religii i socjologii moralności, niedościgłym erudytą i diagnostykiem. Jest badaczem niezależnym, nie pisze pod niczyje dyktando, nie upiększa rzeczywistości, nie chce się nikomu przypodobać, nie ucieka przed tematami trudnymi i kontrowersyjnymi. Przeciwnie — usiłuje w naukowej formule dokonać 
obiektywnej i rzetelnej diagnozy aktualnych problemów społecznych oraz wskazać probabilistyczne kierunki zmian. Jest uczonym rzetelnych diagnoz, mądrych i uczciwych interpretacji, generalizacji i teorii oraz rozsądnych i trafnych refleksji wobec przyszłości (Świątkiewicz, red., 2019, s. 21-37).

Mariański należał lub należy do wielu towarzystw naukowych w kraju i za granicą (np. do Towarzystwa Naukowego KUL, Polskiego Towarzystwa Socjologicznego, Centralnej Komisii ds. Stopni i Tytułów, Zespołu ds. Dobrych Praktyk Akademickich czy Görres-Geselschaft) (Marczewski, 2018, s. 17-18). Pod jego kierownictwem stopień naukowy doktora uzyskało około 60 osób, m.in.: Andrzej Tarczyński (1990), Ewa Budzyńska (1990), Mariusz Zemło (1994) Emilia Żereł (1998) i Leon Smyczek (2002). Wśród jego doktorantów znalazł się również Ondrej Štefaňak ze Słowacji, który od 2008 do 2017 roku wykładał na Katolickim Uniwersytecie w Rużomberku oraz od 2017 roku wykłada na Uniwersytecie Konstantyna Filozofa w Nitrze - obecnie jest kierownikiem Katedry Socjologii na tejże uczelni (Fel, Zemło, red., 2020, s. 635-658).

Štefaňak urodził się 24 grudnia 1979 roku w Keżmarku na Słowacji. W 1998 roku uzyskał maturę. W latach 1998-2003 studiował na Uniwersytecie Komeńskiego w Bratysławie, a w latach 2003-2004 na Wydziale Teologicznym Katolickiego Uniwersytetu w Rużomberku. W okresie 2005-2008 odbył studia doktoranckie na Wydziale Nauk Społecznych KUL Jana Pawła II pod merytorycznie wspomagającym i życzliwym kierownictwem Mariańskiego, który zabierał go na różne konferencje lub spotkania socjoreligijne, wprowadzając go do społeczności socjologów religii w Polsce i na Słowacji. W 2008 roku otrzymał stopień doktora nauk humanistycznych w zakresie socjologii na podstawie rozprawy pt. Postawy religijno-moralne młodzieży diecezji spiskiej. W 2015 roku uzyskał habilitację w zakresie socjologii również na Wydziale Nauk Społecznych KUL Jana Pawła II (Smyczek, 2015b, s. 814-815).

Zainteresowania naukowe Štefaňaka skupiają się przede wszystkim wokół socjologii religii, socjologii moralności oraz katolickiej nauki społecznej. Jest autorem kilkunastu monografii oraz ponad 100 artykułów naukowych. Działa w Radach Naukowych kilku słowackich i zagranicznych czasopism. Jest członkiem Słowackiego Towarzystwa Socjologicznego przy Słowackiej Akademii Nauk, członkiem Komisji ds. Stosunków Polsko-Czeskich i Polsko-Słowackich przy Polskiej Akademii Nauk, ekspertem Słowackiej Agencji Akredytacyjnej ds. Szkolnictwa Wyższego, ekspertem watykańskiej Agencji ds. Oceny i Promocji Jakości Kształcenia na Uniwersytetach i Wydziałach Kościelnych w dziedzinie nauk społecznych (AVEPRO) oraz członkiem Międzynarodowego Stowarzyszenia Badań nad Religią w Europie Środkowo-Wschodniej (ISORECEA) (Skrzyniarz, 2018b, s. 461).

Wśród badań empirycznych oraz bazujących na nich publikacji omawianego socjologa znajdują się dzieła o charakterze monograficznym i podręcznikowym, m.in.: Religijność młodzieży słowackiej. Na przykładzie diecezji spiskiej, 2009; Úvod do sociológie [Wstęp do socjologii], 2009; Wartości moralne maturzystów stowackich. Na przykładzie diecezji spiskiej, 2013; Úvod do katolíckej sociálnej 
náuky [Wstęp do katolickiej nauki społecznej], 2013; Moralność młodzieży w opinii nauczycieli, 2014; Religijni i moralni?, 2014; Globalny stosunek do wiary młodzieży słowackiej w procesie przemian, 2018; Hodnoty, túžby a obavy mládeže [Wartości, dażenia i obawy młodzieży], 2018; Religiozita mládeže v procese premien [Religijność mlodzieży w procesie przemian], 2019; Manželstvo a rodina v ponímaní mládeže [Malzeństwo i rodzina w świadomości młodzieży], 2020; Úvod do sociológie náboženstva [Wstęp do socjologii religii], 2021 (https://www.ukf.sk/univerzita/ kontakt/adresar-osob [dostęp: 28.01.2021]).

Oprócz licznych prac empirycznych Štefaňaka, wykorzystujących przede wszystkim własne badania empiryczne nad religijnością i moralnością młodzieży słowackiej, dla rozwoju tego typu badań na Słowacji istotne jest również, że od 2008 roku pod jego kierownictwem różne stopnie naukowe uzyskało wielu studentów Katolickiego Uniwersytetu w Rużomberku oraz Uniwersytetu Konstantyna Filozofa w Nitrze, których prace dyplomowe (doktorskie, magisterskie lub licencjackie) niejednokrotnie bazowały na badaniach socjoreligijnych. Do studentów tych należą m.in.: Branislav Dubovec (2012), Martina Ziburová (2014), Jozef Virdzek (2016), Martin Majda (2017), Jozef Bartoš (2017), Peter Janáček (2017) i Inga Kolomiyets (2019) (Štefaňak, 2021a).

Štefaňak na podstawie ostatnich trzech spisów ludności oraz własnych i innych badań socjologicznych podkreśla, że po trzech dekadach transformacji polityczno-społecznej i kulturowej religijność w społeczeństwie słowackim pozostaje na względnie stabilnym poziomie. Dotyczy to $-\mathrm{z}$ pewnymi zastrzeżeniami również środowisk młodzieżowych. Zmiany w strukturach społecznych na Słowacji zachodzą znacznie szybciej niż zmiany w sferze aksjologicznej. Przemiany w religijności młodzieży słowackiej nie są procesem ani jednokierunkowym, ani jednolitym. Nie muszą one przypominać do złudzenia schematów rozwojowych zachodnioeuropejskiej dechrystianizacji, są możliwe alternatywne scenariusze przemian socjoreligijnych. Na razie wyniki jego badań empirycznych wspierają przede wszystkim scenariusz powolnie postępującej sekularyzacji, ale częściowo także scenariusz stabilizacji lub nawet rewitalizacji religijności wśród pewnej części młodego pokolenia Słowaków (Smyczek, 2015b, s. 814-815).

Zarysowane stwierdzenia bardzo trafnie dokumentuje typologia religijności młodzieży słowackiej, którą omawiany uczony opracował na podstawie dwóch badań socjoreligijnych przeprowadzonych w środowisku młodzieży diecezji spiskiej w latach 2006 i 2016. Wyróżnił następujące cztery typy religijności:

1. Religijność zorientowana kościelnie $(2006-15,9 \%$; 2016 - 14,9\%). Ten typ religijności cechuje się wysokim poziomem wskaźników religijności we wszystkich jej podstawowych wymiarach. Nie oznacza to, że młodzież o religijności kościelnej nie zna jakichkolwiek odchyleń od oficjalnej nauki Kościoła, jednakże różnice te nie są liczne i nie dotyczą centralnych punktów wiary religijnej.

2. Religijność zorientowana selektywnie (2006 - 38,3\%; $2016-29,5 \%)$. Osoby o religijności selektywnej wybierają z depozytu wiary to, co odpowiada ich subiektywnym potrzebom i opiniom. Niektóre praktyki religijne praktykują 
częściej, inne rzadziej; niektóre wierzenia religijne lub zasady moralne akceptują, innych nie akceptują.

3. Religijność wahająco-poszukująca (2006 - 31,3\%; 2016 - 37,7\%). Młodzież o takich postawach nie ignoruje całkowicie problemów religijnych, ale też nie aprobuje automatycznie zinstytucjonalizowanej religii. Są to osoby niezdecydowane, pytające, wątpiące, ale też poszukujące odpowiedzi w sprawach religijnych.

4. Obojętność lub niewiara $(2006-14,5 \% ; 2016-17,9 \%)$. Chodzi o osoby otwarcie deklarujące obojętność wobec wiary religijnej lub niewiarę. Typ „niewierzących” wskazuje na ludzi, którzy nie przyjmują oficjalnych modeli religijnych oraz tworzą dla siebie nowe, własne interpretacje życia i świata.

Podsumowując przedstawioną typologię, można powiedzieć, iż religijność większości dwukrotnie badanej młodzieży była nacechowana selektywnie albo wahająco $(2006-69,6 \% ; 2016-67,2 \%)$. Z jednej strony $\mathrm{z}$ tą większością graniczyła część młodzieży o religijności zorientowanej kościelnie, a z drugiej strony część młodzieży obojętnej wobec wiary religijnej lub niewierzącej (Štefaňak, 2019, s. 227-233).

\section{Wojciech Świątkiewicz oraz badania nad religijnością L’ubora Gála}

Do wybitnych polskich socjologów religii należy również prof. Wojciech Świątkiewicz, który od lat jest związany z Uniwersytetem Śląskim w Katowicach, ale podczas ostatnich kilkunastu lat również z Uniwersytetem Konstantyna Filozofa w Nitrze. Lista jego prac naukowych obejmuje ponad 200 tytułów i ciągle się poszerza. Urodził się 2 kwietnia 1951 roku w Gdańsku. W 1979 roku obronił na Uniwersytecie Łódzkim doktorat $\mathrm{z}$ nauk humanistycznych w zakresie socjologii. Habilitował się w 1988 roku, a tytuł profesora otrzymał w 1998 roku. Od 1975 roku wykłada na Uniwersytecie Śląskim w Katowicach, na którym pełnił również liczne funkcje akademickie (np. dyrektor Instytutu Socjologii UŚ, prodziekan Wydziału Nauk Społecznych UŚ, prorektor UŚ).

Jego zainteresowania naukowe skupiają się wokół socjologii kultury, socjologii regionu, socjologii religii i socjologii rodziny (https://silesia.edu.pl/index. php/\%C5\%9Awi\%C4\%85tkiewicz_Wojciech [dostęp: 28.01.2021]). Wśród jego publikacji znajdują się m.in. następujące dzieła monograficzne: Integracja kulturowa i jej społeczne uwarunkowania, 1987; Tradycja i wybór. Socjologiczne studium religijności na Górnym Ślasku, 1997; Rodzina w sercu Europy. RybnikNitra - Hradec Králové - Szeged. Socjologiczne studium rodziny wspótczesnej, 2009; Między sekularyzacja i deprywatyzacja. Socjologiczne studium religijności polskiej w kontekście europejskim, 2010; Religiousness and Lifestyles. A sociolo- 
gical Study of Slovak Families [Religijność i style życia. Studium socjologiczne rodzin stowackich], 2017. (https://publons.com/researcher/3579072/wojciechswiatkiewicz/publications/ [dostęp: 28.01.2021]).

Zainteresowania naukowe Świątkiewicza obejmują szczególnie region śląski, problematykę społeczno-kulturowych uwarunkowań wzorów religijności, przekazu wartości religijnych w rodzinie, tradycyjnej religijności w kontekście przemian religijności współczesnej czy też roli religii w procesach legitymizacji świata społecznego. Badacz należał lub należy do wielu towarzystw naukowych w kraju i za granicą (np. do Komitetu Socjologii Polskiej Akademii Nauk, Centralnej Komisii ds. Stopni i Tytułów, Polskiego Towarzystwa Socjologicznego, Polskiego Stowarzyszenia Familiologicznego, Komisji ds. Stosunków Polsko-Czeskich i Polsko-Słowackich i Słowackiego Towarzystwa Socjologicznego) (https://silesia. edu.pl/index.php/\%C5\%9Awi\%C4\%85tkiewicz_Wojciech [dostęp: 28.01.2021]). Pod kierunkiem śląskiego uczonego stopień naukowy doktora uzyskało około 30 osób, m.in.: Dorota Pawlik (1999), Andrzej Kasperek (2001), Andrzej Górny (2005), Agnieszka Skołucka (2009) i Monika Grotek (2014) (https://nauka-polska. $\mathrm{pl} / \# /$ profile/scientist?id=68697\&_k=tahsxo [dostęp: 28.01.2021]). Wśród jego doktorantów - na Uniwersytecie Konstantyna Filozofa w Nitrze — znalazł się również L’ubor Gál ze Słowacji, który obecnie pracuje jako duszpasterz i okolicznościowo wykłada socjologię na tejże uczelni. Chociaż formalnie obronił pracę doktorską pod kierunkiem Petera Kondrly, w znacznej mierze uważa się za ucznia Świątkiewicza, który oprócz niego wypromował w Nitrze kilkunastu absolwentów socjologii, którzy w swoich pracach dyplomowych niejednokrotnie odwoływali się do badań socjoreligijnych.

Gál urodził się 6 grudnia 1979 roku w Nowych Zamkach na Słowacji. W 1998 roku uzyskał maturę. W latach 1999-2007 studiował na Uniwersytecie Komeńskiego w Bratysławie oraz uzyskał magisterium w zakresie teologii katolickiej. W latach 2011 - 2013 odbył studia doktoranckie w Katedrze Socjologii Wydziału Filozoficznego Uniwersytetu Konstantyna Filozofa w Nitrze, w znacznej mierze pod kierunkiem Świątkiewicza, chociaż formalnie pod kierunkiem Kondrly. W 2013 roku otrzymał stopień doktora socjologii na podstawie rozprawy pt. Náboženské hodnoty vo farskom spoločenstve $v$ Nitre [Wartości religijne w społeczności parafialnej w Nitrze]. W latach 2007-2011 pracował jako wikariusz w Złotych Morawcach, a w okresie 2011-2014 jako wikariusz w Nitrze. Od 2014 roku jest proboszczem w parafii Nowa Wiesz nad Żytawą (Gál, 2021).

Zainteresowania naukowe Gála skupiają się wokół socjologii religii, socjologii parafii i socjologii Internetu. Wśród badań empirycznych oraz bazujących na nich publikacji znajdują się m.in. następujące prace naukowe słowackiego uczonego: Náboženské hodnoty v Katechizme Katolickej cirkvi - substanciálne vymedzenie náboženstva v sociológii [Wartości religijne w Katechizmie Kościoła katolickiego - substancjalne definiowanie religii w socjologii], 2013; Tri aspekty skúmania hodnôt [Trzy aspekty badania wartości], 2013; Chudoba a jej etické aspekty [Ubóstwo oraz jego aspekty etyczne], 2014; Médiá — hodnoty - spolo-

256 čnost' [Media - wartości - społeczeństwo], 2014; K sociologickej diferenciácii 
vplyvov vzdelania [Ku dyferencjacii socjologicznej wpływów wykształcenia], 2015; Vzdelanie a religiozita [Wyksztatcenie i religijność], 2015 (https://kis.ukf.sk/opa $\mathrm{cXE}$ ? $\mathrm{fn}=$ resultform\&rankfield $=$ true\&prequelF $=4$ [dostęp: 28.01.2021]). Chociaż Gál nie pracuje przede wszystkim naukowo, w związku z czym nie promuje kolejnej kadry socjoreligijnej, własnymi refleksjami teoretycznymi i analizami empirycznymi z zakresu sojologii religii, socjologii parafii oraz socjologii Internetu chętnie dzieli się przy okazji różnych konferencji lub spotkań naukowych i religijnych.

\section{Zakończenie}

Po przedstawieniu kilku wybitnych polskich socjologów religii (Władysława Piwowarskiego, Janusza Mariańskiego i Wojciecha Świątkiewicza) oraz ich uczniów, którzy pochodzą ze Słowacji oraz (lub) tam pracują (Kamila Kardisa, Ondreja Štefaňaka i L'ubora Gála), należy powtórzyć, iż na rozwój badań nad religijnością w realiach słowackich największy wpływ wywarła polska szkoła socjologiczna (lubelska, katowicka, warszawska, krakowska, poznańska i inne). Oprócz wymienionych naukowców z pewnością istnieją jeszcze inni Słowacy, którzy studiowali w Polsce — np. na Wydziale Teologii KUL Jana Pawła II w Lublinie, na Wydziale Teologii Uniwersytetu Kardynała Stefana Wyszyńskiego w Warszawie (wcześniej Akademii Teologii Katolickiej w Warszawie), na Wydziale Teologii Uniwersytetu Papieskiego Jana Pawła II w Krakowie (wcześniej Papieskiej Akademii Teologicznej w Krakowie), ale też w innych polskich ośrodkach naukowych — i zajmują się problematyką socjoreligijną.

To, że w tym zakresie znaczenie polskich socjologów religii jest pierwszorzędne, nie oznacza, że na rozwoj badań nad religijnością na Słowacji nie miały wpływu również inne szkoły socjologiczne (np. francuska, angielska, włoska, niemiecka, hiszpańska, amerykańska, austriacka, węgierska czy czeska). Jednak oddziaływanie polskiej szkoły socjologicznej wydaje się najistotniejsze — zarówno ze względu na bliskość językową, jak i ze względu na podobne realia socjoreligijne w Polsce i na Słowacji. Opisywany wpływ jest widoczny także w odniesieniu do wątków tematycznych, jak również metodologicznych (np. badania nad religijnością w ramach jej siedmiu podstawowych wymiarów wyróżnionych przez Piwowarskiego kontynuowane przez Mariańskiego, Świątkiewicza, Kardisa, Štefaňaka, Gála i innych). 


\section{Bibliografia}

Fel S., Zemło M., red., 2020: Wokół życia i dzieła Księdza Janusza Mariańskiego. Biografia z socjologia w tle (1940-2020). Lublin: Wydawnictwo KUL.

Gál L., 2013: Náboženské hodnoty v Katechizme Katolickej cirkvi - substanciálne vymedzenie náboženstva v sociológii. W: Sociálne posolstvo Jána Pavla II. pre dnešný svet 2013. Red. A. Lisník, K. Greňová, M. Ambrózy, I. Franzenová. Ružomberok: Verbum, s. $146-155$.

Gál L., 2015a: K sociologickej diferenciácii vplyvov vzdelania. „Mládež a spoločnost”, nr. 3, s. $26-35$.

Gál L., 2015b: Vzdelanie a religiozita. Nitra: Univerzita Konštantína Filozofa v Nitre.

Gál L., 2021: Życiorys. Archiwum prywatne Lubora Gála.

Gál L., Kondrla P., Pavlíková M., Pavlovičová P., 2013: Tri aspekty skúmania hodnôt. Ljubljana: KUD Apokaslipsa.

Gál L., Šarvajcová M., 2014a: Chudoba a jej etické aspekty. Košice: UPJŠ.

Gál L., Šarvajcová M., 2014b: Média - hodnoty - spoločnost'. W: (Ko)media. (Ko)munikacja, (Ko)operacja, (Ko)ntestacja. Red. Z. Widera, L. Čábyová. Katowice: Wydawnictwo Naukowe Unikat 2, s. 151-158.

Kardis K., 2009: Základy sociológie. Prešov: Prešovská univerzita v Prešove.

Kardis K., 2013a: Náboženstvo v kontexte paradigmy sociálnej zmeny. Prešov: Vydavatel'stvo Prešovskej univerzity.

Kardis K., 2013b: Vybrané kapitoly zo sociológie náboženstva I. Prešov: Prešovská univerzita v Prešove.

Kardis K., 2016: Sociológia náboženstva II. Prešov: Prešovská univerzita v Prešove.

Kardis K., 2017: Kapitał społeczny a religia w perspektywie społeczeństwa ryzyka. Warszawa: Jedność w Różnorodności.

Kardis K., Nguyen Trong D., 2019: Úvod do kultúrnej a sociálnej antropológie. Prešov: Vydavatel'stvo Prešovskej univerzity.

Libiszowska-Żółtkowska M., Mariański J., red., 2004: Leksykon socjologii religii. Warszawa: Verbinum.

Marczewski M., 2018: Mariański Janusz. W: Encyklopedia 100-lecia KUL. T. II. Red. A. Dębiński. Lublin: Wydawnictwo KUL, s. 17-18.

Mariański J., 2001: Kryzys moralny czy transformacja wartości? Studium socjologiczne. Lublin: Towarzystwo Naukowe KUL.

Mariański J., 2004a: Piwowarski Władysław. W: Leksykon socjologii religii. Red. M. Libiszowska-Żółtkowska, J. Mariański. Warszawa: Verbinum, s. 291-292.

Mariański J., 2004b: Religijność społeczeństwa polskiego w perspektywie europejskiej. Próba syntezy socjologicznej. Kraków: Zakład Wydawniczy Nomos.

Mariański J., 2006a: Sekularyzacja i desekularyzacja w nowoczesnym świecie. Lublin: Wydawnictwo KUL.

Mariański J., 2006b: Socjologia moralności. Lublin: Wydawnictwo KUL.

Mariański J., 2008: Emigracja z Kościoła. Religijność młodzieży polskiej w warunkach zmian społecznych. Lublin: Wydawnictwo KUL.

$\frac{\sqrt{0}}{\frac{0}{\pi}}$ Mariański J., 2010: Religia w społeczeństwie ponowoczesnym. Warszawa: Oficyna Naukowa.

Mariański J., 2011: Przemiany moralności polskich maturzystów w latach 1994-2009. Studium socjologiczne. Lublin: Wydawnictwo KUL. 
Mariański J., 2014: Kontrowersje wokót relacji religii i moralności. Tożsamość czy rozbieżność? Studium socjologiczne. Toruń: Wydawnictwo Adam Marszałek.

Mariański J., 2017: Godność ludzka w kontekście społecznym. Szkice ze społecznego nauczania Kościoła katolickiego. Lublin: Gaudium.

Mariański J., 2018: Kondycja religijna $i$ moralna młodzieży szkót średnich $w$ latach 1988-1998-2005-2017. Toruń: Wydawnictwo Adam Marszałek.

Mariański J., red., 2015: Leksykon socjologii moralności. Podstawy, teorie, badania, perspektywy. Red. Idem. Kraków: Zakład Wydawniczy Nomos.

Piwowarski W., 1971: Religijność wiejska w warunkach urbanizacji. Studium socjologiczne. Warszawa: Biblioteka „Więzi”.

Piwowarski W., 1977: Religijność miejska w rejonie uprzemysłowionym. Studium socjologiczne. Warszawa: Biblioteka „Więzi”.

Piwowarski W., 1993: ABC katolickiej nauki społecznej. Pelplin: Wydawnictwo Diecezjalne.

Piwowarski W., 2000: Socjologia religii. Lublin: Redakcja Wydawnictw KUL.

Piwowarski W., red., 1983: Religijność ludowa - ciagłość i zmiana. Wrocław: Wydawnictwo Wrocławskiej Księgarni Archidiecezjalnej.

„Sociológia”, 2001, nr 1.

Skrzyniarz R., 2018a: Kardis Kamil. W: Encyklopedia 100-lecia KUL. T. I. Red. A. Dębiński. Lublin: Wydawnictwo KUL, s. 461.

Skrzyniarz R., 2018b: Štefan̆ak Ondrej. W: Encyklopedia 100-lecia KUL. T. II. Red. A. Dębiński. Lublin: Wydawnictwo KUL, s. 461.

Smyczek L., 2015a: Mariański Janusz. W: Leksykon socjologii moralności. Podstawy, teorie, badania, perspektywy. Red. J. Mariański. Kraków: Zakład Wydawniczy Nomos, s. $385-386$.

Smyczek L., 2015b: Štefan̆ak Ondrej. W: Leksykon socjologii moralności. Podstawy, teorie, badania, perspektywy. Red. J. Mariański. Kraków: Zakład Wydawniczy Nomos, s. $814-815$.

Štefaňak O., 2009a: Religijność młodzieży słowackiej. Na przykładzie diecezji spiskiej. Ružomberok: Pedagogická fakulta Katolíckej univerzity v Ružomberku.

Štefaňak O., 2009b: Úvod do sociológie. Ružomberok: Pedagogická fakulta Katolíckej univerzity v Ružomberku.

Štefaňak O., 2013a: Úvod do katolíckej sociálnej náuky. Ružomberok: Verbum.

Štefaňak O., 2013b: Wartości moralne maturzystów słowackich. Na przykładzie diecezji spiskiej. Lublin: Norbertinum.

Štefaňak O., 2014a: Moralność młodzieży w opinii nauczycieli. Lublin: Norbertinum.

Štefaňak O., 2014b: Religijni i moralni? Lublin: Norbertinum.

Štefaňak O., 2018a: Globalny stosunek do wiary młodzieży słowackiej w procesie przemian. Katowice: Studio Noa.

Štefaňak O., 2018b: Hodnoty, túžby a obavy mládeže. Nitra: Univerzita Konštantína Filozofa $v$ Nitre.

Štefaňak O., 2019: Religiozita mládeže v procese premien. Nitra: Univerzita Konštantína Filozofa v Nitre.

Štefaňak O., 2020: Manželstvo a rodina v ponímaní mládeže. Nitra: Univerzita Konštantína Filozofa v Nitre.

Štefaňak O., 2021a: Prace dyplomowe. Archiwum prywatne Ondreja Štefaňaka.

Štefaňak O., 2021b: Úvod do sociológie náboženstva. Nitra: Univerzita Konštantína Filozofa v Nitre. 
Świątkiewicz W., 1987: Integracja kulturowa i jej społeczne uwarunkowania. Katowice: Wydawnictwo Uniwersytetu Śląskiego.

Świątkiewicz W., 1997: Tradycja i wybór. Socjologiczne studium religijności na Górnym Ślasku. Katowice-Wrocław: Societas Scientiis Favendis Silesiae Superioris.

Świątkiewicz W., 2010: Między sekularyzacja i deprywatyzacją. Socjologiczne refleksje wokół polskiej religijności w kontekście europejskim. Katowice: Wydawnictwo Uniwersytetu Ślaskiego.

Świątkiewicz W., Górny A., Juszczyk-Frelkiewicz K., 2017: Religiousness and Lifestyles. A Sociological Study of Slovak Families. Katowice: University of Silesia.

Świątkiewicz W., red., 2009: Rodzina w sercu Europy. Rybnik - Nitra - Hradec Králové - Szeged. Socjologiczne studium rodziny współczesnej. Katowice: Wydawnictwo Uniwersytetu Śląskiego.

Świątkiewicz W., red., 2019: Janusz Mariański. Doctor Honoris Causa Universitatis Silesiensis. Katowice: Wydawnictwo Uniwersytetu Śląskiego.

Święs K., 2018: Piwowarski Władystaw. W: Encyklopedia 100-lecia KUL. T. II. Red. A. Dębiński. Lublin: Wydawnictwo KUL, s. 187-188.

Zemło M., 2009: Recenzja. O. Štefan̆ak: Religijność młodzieży słowackiej. Na przykładzie diecezji spiskiej. Lublin: Norbertinum.

\section{Źródla internetowe}

http://www.pulib.sk/web/kniznica/epc/autor/Kardis+Kamil+\%281976\%29 [dostęp: 28.01. 2021].

https://kis.ukf.sk/opacXE?fn=resultform\&rankfield=true\&prequelF=4 [dostęp: 28.01 . 2021].

https://kzp.pulib.sk/\#/library/kzp?supervisor=Kardis\%20Kamil [dostęp: 28.01.2021]. https://nauka-polska.pl/\#/profile/scientist?id=68697\&_k=tahsxo [dostęp: 28.01.2021]. https://publons.com/researcher/3579072/wojciech-swiatkiewicz/publications/[dostęp:28.01. 2021].

https://silesia.edu.pl/index.php/\%C5\%9Awi\%C4\%85tkiewicz_Wojciech [dostęp: 28.01 . 2021].

https://www.ukf.sk/univerzita/kontakt/adresar-osob [dostęp: 28.01.2021]. https://www.unipo.sk/greckokatolicka-teologicka-fakulta/katedry/kfr/7/kkardis/op/ [dostęp: 28.01.2021]. 